\title{
Farmers' Valuation of Agro-Biodiversity in Home Gardens: Case Study in the Kurunegala District
}

\author{
I. V. Kuruppu ${ }^{1}$, J. C. Edirisighe", \#, H. M. L. K. Herath', \\ U. K. Jayasinghe-Mudalige ${ }^{1}$, W. Wijesuriya ${ }^{2}$, \\ J. M. M. Udugama ${ }^{1}$ and A. P. S. Fernando ${ }^{3}$ \\ ${ }^{1}$ Dept. of Agribusiness Management, \\ Faculty of Agriculture and Plantation Management, \\ Wayamba University of Sri Lanka, Makandura, Gonawila (NWP) \\ ${ }^{2}$ Rubber Research Institute of Sri Lanka, Agalawatta, Sri Lanka
}

${ }^{3}$ Rajarata University of Sri Lanka, Mihintale

\#Corresponding Author

Tele: (94) 31229 9246; Fax: (94) 31229 9248; E-mail: jagathed@yahoo.com

\begin{abstract}
Agro-biodiversity acts as a key environment resource that enhances the sustainability in any given eco-system. Much of the agro-biodiversity remaining in situ today is found on the semi-subsistence farms, small scale farms or home gardens. Labeled "home gardens" as a reflection of their institutional identity during the collectivization period, they are micro-agro ecosystems that provide important environmental functions and food security. This study applies the choice experiment method to estimate the private benefits farmers derive from four components of agro-biodiversity in the home gardens; richness of crop varieties and fruit trees, crop landraces, integrated crop and livestock production and soil microorganism diversity. Primary data collected from a sample of 189 households in the Kurunegala was used in this study. A conditional logit model was used to elicit willingness to accept by home garden owners for preserving above mentioned facets of agro-biodiversity. Results highlighted that the households' highest willingness to accept attribute was livestock integration. In addition other attributes such as organic production, landraces, pollination, fauna and flora diversity were significant components of a home garden. Findings demonstrate variation in the private values of home gardens and their attributes across households contributing to understand the potential role of home gardens in the area. This study has implications for sustaining agro-biodiversity in home gardens and in the country.
\end{abstract}

KEYWORDS: Agro-biodiversity, Choice experiment, Home gardens, Willingness to accept 


\section{Introduction}

Agro-biodiversity is a subset of natural biodiversity, which includes the plant genetic resources used for food and agriculture (cultivars, landraces, ecotypes, weedy races and wild relatives) (Negri, 2009). Maintaining such genetic variation within agricultural crops provides a broad range of essential goods and services which support ecosystem functioning, resilience and productivity (Tilman, 1999). Therefore, it has become a core principle of sustainable agriculture and agroecology. Home garden is a complex sustainable land use system that combines multiple farming components, such as annual and perennial crops, livestock and occasionally fish, of the homestead and provides environmental services, household needs and employment and income generation opportunities to the household (Weerahewa et al., 2012).

Nevertheless, loss of agro-biodiversity in the recent past has given global efforts to improve conservation actions through a number of international documents and agreements. The Convention on Biological Diversity CBD (1992) aims to halt the current loss of plant and crop diversity while assisting poverty reduction and sustainable development. It is believed that as opposed to ex-situ conservation, insitu, on farm conservation in farmer field and gardens is "dynamic" because it ensures the continuous adaptation of species and landraces within a changing environment and relies upon both human and biological components of the ecosystem. Much of the agro-biodiversity remaining in situ today is found on the semi-subsistence farms of poorer countries and on the small-scale farms and home gardens of more industrialized nations (Brookfield, 2001).

In Sri Lanka, home gardens have been an integral part of the landscape and culture for centuries (De Silva, 1981). The land use systems in Sri Lanka at present are challenged as never being before with mounting concerns of environment on one hand and pressure of economic development on the other. Land use system not evaluate only on their ability to fulfill any single objective such as production of a selected commodity, but also on how best they fulfill the sustainability criteria. Over the years, the number and total area of home gardens in Sri Lanka have been increasing annually, with little policy support. The area under home gardens has been reported and widely quoted as $14.3 \%$ based on the reports of Food and Agricultural Organization (FAO, 2009). The total number of home gardens has also continued to grow at a rate of $1.6 \%$ annually (DCS, 2002).

The Haritha Lanka programme of 2009 and the National Agriculture Policy of 2007 also highlights the importance of the home gardens. Development of 375,000 home gardens were aimed under the "Api Wawamu Rata Nagamu” (Let us grow and uplift the nation) programme launched in 2007, and strengthening of 1.5 million home gardens is the target of "Divi Neguma" (Livelihood Development) programme in order to achieve self-sufficiency (Government of Sri Lanka, 2011). 
At the movement there are capital constraints and market barriers to extension of home gardens into commercial farms. On the demand side, it is predicted that the consumption risks, transaction costs and low wages that bring about dependency on home garden food will decrease with increased market access and price stability (Ferto et al., 2004). Therefore, specific objective of this study was to assess agroenvironmental measures to ensure continuation of home gardens, unless the survival of home gardens is likely to be threatened by the structure of incentives, economic and social changes.

\section{Methodology}

\section{Theoretical Framework}

When considering the home garden most of the functions and services are not traded in the markets, therefore non-market valuation methods must be used to determine the values of their benefits. Benefits of most outputs, functions and services that home gardens generate primarily accrue to households in non-market values or utility. Because these households are both, producers and consumers, their preferences determine the implicit values they attach to home gardens and their attributes. This study intends to use Choice Experimentation Technique in valuation, because it enables estimation not only of the value of the environmental asset as a whole, but also of the implicit values of its attributes (Hanley et al., 1998).

This technique has theoretical consistency in line with the Lancaster's model of consumer choice (Lancaster, 1966) and also has an econometric basis in models of random utility. Lancaster proposed that consumers derive satisfaction not from goods themselves but from the attributes they provide. In this technique, a utility function $\left(\mathrm{U}_{\mathrm{ij}}\right)$ as derived from home gardens is specified and behavior is integrated into this function by Random Utility approach, where utility of a choice is comprised of a deterministic component (V) and an error component (e), which is independent of the deterministic part and follows a predetermined distribution. Thus, the utility can be specified as;

$$
\mathbf{U}_{\mathrm{ij}}=\mathbf{V}\left(\mathbf{Z}_{\mathbf{j}}, \mathbf{S}_{\mathrm{i}}\right)+\mathbf{e}\left(\mathbf{Z}_{\mathbf{j}}, \mathbf{S}_{\mathrm{i}}\right)
$$

For any given household $i$, a given level of utility will be associated with any alternative home garden $j$. Therefore, utility derived from any of the home garden alternative depends on the attributes $(Z)$ of the home garden and the social and economic characteristics (S) of households. This error component implies that the predictions cannot be made with certainty. Choices made between alternatives will be a function of the probability that the utility associated with a particular option $(j)$ is higher than that the utility associated with other alternatives. Assuming that the relationship between utility and characteristics is linear in the parameters and variables function, and that the error terms are identically and independently distributed with a Weibull distribution, the probability of any particular alternative $j$ 
being chosen can be expressed in terms of a logistic distribution (Birol et al., 2006) This equation can be estimated using a Conditional Logit model. Once estimated, parameters of the model could be used to obtain a part-worth or implicit price formula for the marginal rate of substitution between income and an attribute concerned as;

$$
W=-1\left(\frac{\beta_{\text {attribute }}}{\beta_{\text {monetaryattribute }}}\right)
$$

This is the marginal welfare measure that seek for a change in any of the attributes (relevant to agro-biodiversity in home gardens), sometimes known as the Willingness-to-Pay (WTP) or the Willingness-to-Accept (WTA).

\begin{tabular}{|c|c|c|c|c|}
\hline \multicolumn{5}{|c|}{ Main block 01} \\
\hline & & $\begin{array}{c}\text { Home garden } \\
1\end{array}$ & $\begin{array}{c}\text { Home garden } \\
2\end{array}$ & $\begin{array}{l}\text { Home garden } \\
\qquad 3\end{array}$ \\
\hline $\begin{array}{l}\text { Total number of crops in the home } \\
\text { garden }\end{array}$ & & 25 & 10 & 15 \\
\hline $\begin{array}{l}\text { Total number of animals in the } \\
\text { home garden }\end{array}$ & $\sin ^{2}$ & 15 & 5 & 10 \\
\hline $\begin{array}{l}\text { Landraces usage in the home } \\
\text { garden }\end{array}$ & andescheded & $\begin{array}{l}\text { Both hybrid \& } \\
\text { landraces }\end{array}$ & $\begin{array}{c}\text { Only } \\
\text { landraces }\end{array}$ & $\begin{array}{l}\text { No any } \\
\text { landraces }\end{array}$ \\
\hline $\begin{array}{l}\text { Organic production in the home } \\
\text { garden }\end{array}$ & & $\begin{array}{l}\text { Both organic } \\
\& \text { inorganic }\end{array}$ & Organic only & Inorganic only \\
\hline $\begin{array}{l}\text { Flowering plants from total plants } \\
\text { in the home garden }\end{array}$ & & $50 \%$ & $25 \%$ & $75 \%$ \\
\hline $\begin{array}{l}\text { Livestock production in the home } \\
\text { garden }\end{array}$ & $30^{3}$ 욜 & $\begin{array}{l}\text { Livestock } \\
\text { integration }\end{array}$ & $\begin{array}{l}\text { Only livestock } \\
\text { production }\end{array}$ & No livestock \\
\hline Timber, wood and medicinal usage & की 3 & $75 \%$ & $25 \%$ & $50 \%$ \\
\hline Self-sufficiency & indes & $75 \%$ & $25 \%$ & $50 \%$ \\
\hline
\end{tabular}

This indirect measure is preferred over a direct monetary attribute because most of the outputs and functions of home garden that result in agro-biodiversity are not traded in the market, but consumed by the households themselves. The proxy monetary attribute can easily be converted into actual monetary units by using secondary data on the household expenditure on food consumption.

\section{Study Location and Data}

The study was carried out by partnering with the Community-Based Organization (CBO) in Lihiniwehere Grama Niladari (GN) Division in Rideegama District Secretariat (DS), located in the Kurunegala district in the North Western Province (Figure 2). 


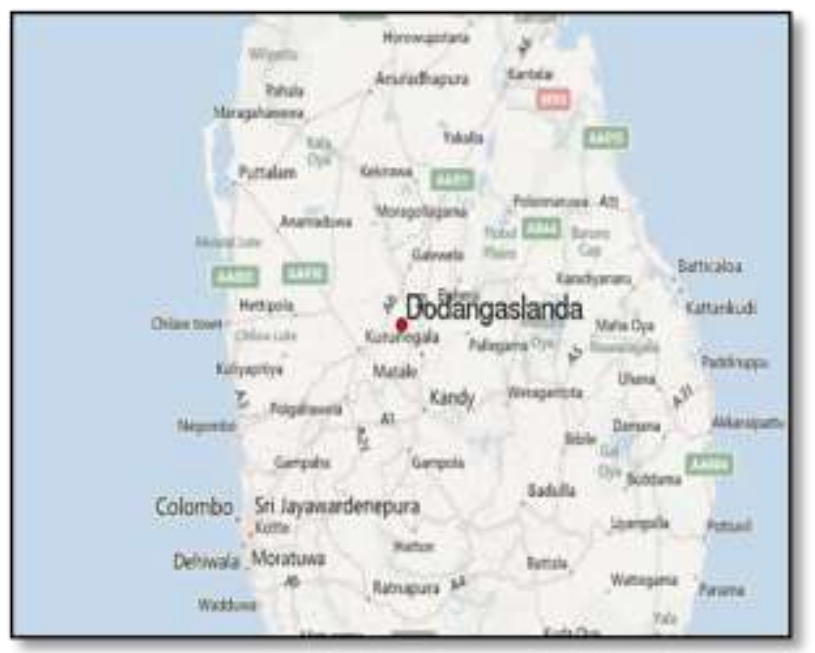

Figure 2: Study location Dodangaslanda

A preliminary survey which consisted with several focus group discussions were carried out to identify the most important attributes and attributes levels in the area. Best three active community-based organizations Lihiniwehera, Arunalu and Pubudu farmer organizations were selected and a total 189 households were randomly selected and interviewed during the period of April to May, 2014. The questionnaire was structured to measure the four components of the agrobiodiversity in the home garden.

\section{Choice Sets}

Choice cards were prepared using the crucial attributes and the attribute levels. An example choice set is presented in Figure 1. A large number of unique home garden profiles can be constructed from this number of attributes and levels. An Orthogonalization procedure was used to recover only the main effects, consisting 27 home garden profiles and profiles were randomly blocked to nine different versions, each with three different home garden alternatives. After the face to face interview for the questionnaire, households were presented with the choice card and each respondent was asked to select the best preferred home garden from the three alternatives.

\section{Data Analysis}

Data were analyzed by using the software Stata version 11.2. Conditional logit approach was used for the data analysis process. For the population represented by the sample, indirect utility from home garden attributes takes the form as shown in equation 3 below. 


$$
\begin{aligned}
V_{i j=\beta}+\beta_{1} \operatorname{In} & \left(Z_{\text {crop spp. }}\right)+\beta_{2} \operatorname{In}\left(Z_{\text {animal spp }}\right)+\beta_{3} \operatorname{In}\left(Z_{\text {landraces }}\right) \\
& +\beta_{4} \operatorname{In}\left(Z_{\text {organic production }}\right)+\beta_{5} \operatorname{In}\left(Z_{\text {flower plants }}\right) \\
& +\beta_{6} \operatorname{In}\left(Z_{\text {livestock }}\right)+\beta_{7} \operatorname{In}\left(Z_{\text {woodimedicine }}\right) \\
& +\beta_{8} \operatorname{In}\left(Z_{\text {self sufficiency }}\right)
\end{aligned}
$$

Where $\beta$ refers to the coefficient, which is specified to account for the proportion of choice of participation in home garden management. The term $\beta_{1-8}$ refers to the vector of coefficients associated with the vector of attributes describing home garden characteristics. The eighth monetary attribute (self-sufficiency) was included in order to estimate welfare charges. The monetary attribute in this choice experiment is a proxy, measuring the level of self-sufficiency in household food consumption the home garden supplies. This final attribute represents WTA compensation.

\section{Results and Discussion}

Out of the total 189, majority (62\%) of the households were males and the rest (38\%) females. From them $52.9 \%$ have completed their secondary education. About $77.8 \%$ households are maintaining their home gardens as a part time activity and from the total sample $42.3 \%$ households are engaged in the home gardening more than 15 years. From the total sample $34.9 \%$ are engaged in the home gardening between 10-15 years. So the majority of households were having the knowledge and the potential to maintain their home gardens as a perfect example for the sustainable home garden concept.

According to the descriptive statistics of the sample (Table 1), livestock integration and the bee keeping in home gardens of the selected area was very low. Respectively lack of space availability and lack of knowledge became the major reasons for above incidences. Organic production and usage of organic manure is high. About $62.4 \%$ of the sample has traditional varieties in their home garden. Most of the households produced only for home consumption.

Disposal of the traditional varieties were mainly occurred via generation to generation $(83.11 \%)$. Commercial versions of these traditional varieties were not available in the market place mainly due to lack of demand towards those varieties. Less productivity was the main issue of those traditional varieties when comparing to hybrids. Current seed requirement was mainly provided by the government agro officers $(57.3 \%)$. Second choice was given towards the commercial traders $(25.4 \%)$. Demand for the hybrids and selecting a commercial trader to purchase those seeds were the current trend in the area. $74.6 \%$ was currently receiving extension on home gardening. 
Table 1. Descriptive statistics of the current maintenance of the home gardens

\begin{tabular}{ccc}
\hline Variables & Frequency & Percentage \\
\hline Traditional Crop spp. & 118 & 62.4 \\
Using & 71 & 37.6 \\
Not using & & \\
Fertilizer Type & 144 & 76.2 \\
Organic & 11 & 5.8 \\
Inorganic & 29 & 15.3 \\
Both & & \\
Pesticide Type & 131 & 69.3 \\
Organic & 19 & 10.1 \\
Inorganic & 18 & 9.5 \\
Both & & 29.6 \\
\hline Livestock Integration & 56 & 70.4 \\
Yes & 133 & \\
No & & 5.8 \\
Bee Keeping & 11 & 94.2 \\
Yes & 178 & 31.2 \\
No & & 68.8 \\
\hline Selling Products & 59 & \\
Yes & 130 & \\
No & & \\
\hline & & \\
\hline
\end{tabular}

Timber crops are the mostly seen crop species (6) in home gardens in the area (Table 2). This is due to its main purpose of provision of timber as well as for the shade and for the beauty that creates by these trees. Apart from these timber crops households also focused on fruit crops, spices and different variety of flower crops in their home gardens. Direct usage of these flower varieties was to create an aesthetic value in the home gardens.

Thus this factor envisaged that the households were also indirectly considered about the pollination factor that ultimately increases the yield component of the home garden products. Tuber crop species (1) and the leafy vegetable crops (2) were the least seen varieties in home gardens.

Maximum number of seven main different animal species was seen in home gardens (Figure 3). Bird, butterfly and reptile species were the prominent species in home gardens. Households were hardly liked the animal component in the home gardens, due to damages done by those species to the harvest. 
Table 2. Current crop species diversity in home gardens

\begin{tabular}{ccc}
\hline Crop Species & $\begin{array}{c}\text { Average per } \\
\text { Home Garden }\end{array}$ & Mostly Seen Species \\
\hline Vegetable crops & 4 & Eggplant (Solanum melongena) \\
Fruit crops & 5 & Banana (Musa spp.) \\
Medicinal plants & 3 & Aloe Vera (Aloe vera) \\
Spices & 5 & Curry leaf (Murraya koenigii) \\
Flower crops & 5 & Idda (Tabernaemontana divaricate) \\
Foliage crops & 3 & Croton (Croton spp.) \\
Tuber crops & 1 & Cassava (Manihot esculenta) \\
Leafy vegetable plants & 2 & Gotukola (Centella asiatica) \\
Timber crops & 6 & Coconut (Cocos nucifera) \\
\hline
\end{tabular}

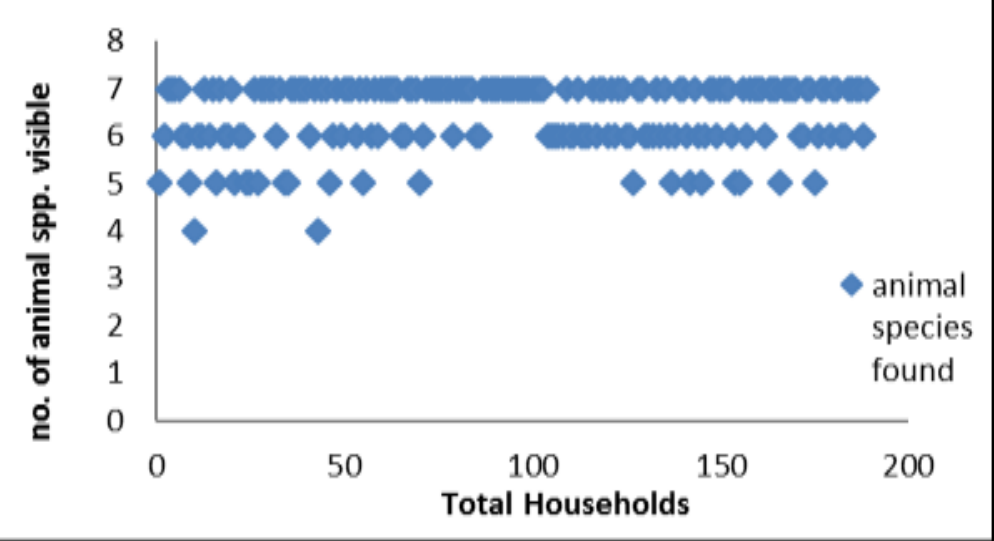

Figure 3: No. of animal species that has been visible in home garden

The results obtained from the conditional regression model are reported with respect to the eight attributes (Table 3). The overall fit of the model as measured by McFadden's $\rho^{2}$ is reasonable by conventional standards used to describe probabilistic discrete choice models.

Organic production, livestock component, combination of landraces and hybrid varieties, crop species, flower crops and raw material usage were significant and positively affected to the home gardens in the area. But, the animal species placed a negative significance and relatively very low demand.

The highest demand was given to the organic concept in the home garden. Studied area has a high potential and trend for the usage of organic concept. Main reason for this can be because households mainly produce for home consumption in home gardens and therefore, they may require the produce to be healthy. 
They were not using any chemicals for the products thus; they were much reliable on the products from the home garden than in the market. Also, the freshness and the quality of the products were high. Furthermore, adaptation to the organic production was a vital part in the home garden. Also, older farmers may have less cash and high transaction costs to purchase chemical inputs, but they also have long experience with labor-intensive, input-extensive production methods. Younger ones with off-farm occupations and education also prefer organic concept.

Table 3: Conditional logit estimates for home garden attributes

\begin{tabular}{ccc}
\hline Variables & Coefficient & P - value \\
\hline 15 Crop spp. & $0.244^{* *}$ & 0.025 \\
25 Crop spp. & 0.135 & 0.208 \\
10 Animal spp. & -0.154 & 0.142 \\
15 Animal spp. & $-0.336 * * *$ & 0.001 \\
No landraces & $0.403 * * *$ & 0.003 \\
Landraces + Hybrids & $0.287 * * *$ & 0.002 \\
Inorganic production & -0.122 & 0.215 \\
Organic + Inorganic & $-0.413 * * *$ & $<0.001$ \\
50\% Flower crops & 0.060 & 0.578 \\
75\% Flower crops & $0.219^{* *}$ & 0.046 \\
No livestock & $-0.345^{* * *}$ & 0.001 \\
Livestock + Crop & -0.094 & 0.368 \\
50\% Raw materials & $-0.312^{* * *}$ & 0.006 \\
75\% Raw materials & $0.198^{* *}$ & 0.046 \\
Self-sufficiency & $0.0002 * * *$ & $<0.001$ \\
Age of farmers & $0.003^{* * *}$ & $<0.001$ \\
\hline$\rho^{2}$ & 0.031 & \\
Log likelihood & -330.071 & \\
\hline
\end{tabular}

***Significant at 1\% level, **Significant at 5\% level, *Significant at $10 \%$ level

Maintaining the home garden with traditional varieties was also demanded at a considerable level. They also placed a great importance on crop variety diversity but a very low demand for the animal species diversity. Among the total crops that were allocated to the home gardens, more flower producing crops were required. This revealed that the households considered about the pollination factor that boosts their production. In addition, existences of flowering plants improve the aesthetic value of home gardens and households may be adding value to this aspect as well.

Demand for the raw material usage is also high. Households were utilizing the fuel wood, timber and medicinal benefits as much as possible from their home gardens. Age factor also a significant for maintaining the home garden. Well experienced older farmers knew the importance of a home garden and the main concepts of 
home garden than younger generation. Their attitudes were highly valuable and critical for the maintenance of a home garden. Primary data on the weekly expenditure of a household on food consumption in the studied area were combined with the regression coefficient to compute equation (2), interpreted here as the WTA compensation for a possible loss (Table 4). The results revealed that the households in the studied area attached the highest value to organic production.

Secondly, livestock component of a home garden derived the largest value. This is because the additional income generation as well as the other miscellaneous usage of livestock in home gardens in the area. Though it clearly showed that livestock integration attribute was an important concept to the home garden, in real case households were reluctant to maintain such a component in their home gardens. Only maintenance of the landraces in the home garden was refused, but demand for both landraces and hybrids were requested by the households. Findings revealed that almost all the attributes of a home garden was significant in the studied area.

Table 4: WTA compensation values by the households (Rs./household/week)

\begin{tabular}{cc}
\hline Variables & WTA \\
\hline 15 Crop spp. & $-1220 /=$ \\
15 Animal spp. & $+1680 /=$ \\
Landraces + Hybrids & $-1435 /=$ \\
Organic \& inorganic production & $+2065 /=$ \\
$75 \%$ Flower crops & $-1095 /=$ \\
No Livestock & $+1725 /=$ \\
$75 \%$ Raw materials & $-990 /=$ \\
\hline
\end{tabular}

\section{Conclusions}

This study estimated the private economic value of agro-biodiversity attributes in Kurunegala area home gardens. Findings support the a priori assumption that home garden attributes contributes positively and significantly to the utility of households in the area. The relative importance of the home garden attributes to a household depends on their social and economic factors as well as their education, age, location of the particular individual, family size, gender, landscape heterogeneity and cultural references.

Livestock integration and the organic production are highly valued by the households. Organically produced home gardens are valued by younger, more educated, families with higher incomes, followed by those poorer families with older decision makers. Landraces are attached the highest value by the elderly, experienced home gardeners, who are typically retired. According to the study respondents were almost satisfied with the extension services regarding the home garden. Animal species diversity is not much considered by the households. The 
opportunity cost for farmers of maintaining home gardens are expected to change with the economic changes, rising income and the market development that are meant to occur in Sri Lanka as a consequence of economic transition.

Infrastructure development and new employment opportunities proposed by the national level rural development plans and programs are expected to augment access to markets, reducing the dependence of farm families on their gardens for food needs and diet quality. Furthermore, across regions older farmers attach the highest values to crop genetic resources, and family size is an important determinant of agro-biodiversity management in the home garden. These facts imply that the ongoing migration of younger generation out of isolated regions may result in lower values of agro-biodiversity in home gardens than those estimated in this study.

With social and economic change, there is insufficient assurance that traditional home garden management is sustainable in the long run. The benefit estimates reported in this study represents only the private values of home gardens. A complete analysis of costs and benefits includes the private and public costs and benefits of home garden management, as well as a comparative analysis of policy instruments for achieving related social goals should be done. This analysis is needed before recommendations can be made concerning the inclusion of home gardens in national agro-environment schemes. Furthermore, findings have implications for agro-environmental policies for the studied area.

\section{Acknowledgements}

Authors wish to express their profound gratitude to the members of Lihiniwahera, Arunalu and Pubudu farmer organizations for the support given and the Ministry of Environment and Renewable Energy for providing the financial requirements.

\section{References}

Birol, E., M. Smale and A. Gyovai (2006). "Using a Choice Experiment to estimate farmers' valuation of agro-biodiversity on Hungarian small farms". Journal of Environment and Resources Economics, 34: 439-469.

Brookfield, H. (2001). "Exploring agro diversity". New York: Columbia University Press.

CBD. (1992). "Convention on biological diversity". Secretariat of the convention on biological diversity, United Nations environment program.

DCS. (2002). Agriculture Census. Department of Census and Statistics, Sri Lanka.

De Silva, K. M. (1981). “A history of Sri Lanka”. C. Hurst \& Company, London. University of California Press, Berkley and Los Angeles. 
FAO. (2009). "Sri Lanka forestry sector outlook study by Forest Department". Working Paper No. APFSOS II/WP/2009/29. FAO, Regional Office for the Asia and the Pacific, Bangkok, Thailand.

Ferto, I., Cs. Fogacs, A. Juhasz and Gy. Kurhty (2004). "Regoverning markets, country report, Hungary".

Government of Sri Lanka. (2011). "Improving family nutrition, a main objective of Divi Neguma Programme". Available online: http://www.priu.gov.lk/news_update/ Current Affairs/ca201107/20110713improving_family_nutrition.htm (Accessed 24 March 2014).

Hanley, N., N. R. E. Wright and W. L. Adamowicz (1998). "Using Choice Experiments to value the environment". Environmental and Resource Economics, 11(34): 413-428.

Lancaster, K. (1966). "A new approach to Consumer Theory". Journal of Political Economy, 84, 132-157.

Negri, V. (2009). "Possible incentives to home garden maintenance: comparing possibilities and raising awareness among farmers". In: Proceedings of a workshop on crop genetic resources in European home gardens. Bioversity international, 72-80.

Tilman, D. (1999). "Global environmental impacts of agricultural expansion: the need for sustainable and efficient practices". Proceedings of the National Academy of Sciences, 96: 1857-1861.

Weerahewa, J., G. Pushpakumara, P. Silva, C. Daulagala, R. Punyawardena, S. Premalal, G. Miah, J. Roy, S. Jana and B. Marambe (2012). "Are home garden ecosystems resilient to climate change? An analysis of the adaptation strategies of home gardeners in Sri Lanka". APN Science Bulletin, 2: 22-27. 